\title{
PROPHETICAL DIMENSION IN KHOTBAH DI ATAS BUKIT NOVEL BY KUNTOWIJOYO
}

\author{
Muhammad Ayyinna Yusron El Farouq, Umi Machmudah
}

\author{
ayinfarouq@yahoo.co.id \\ Universitas Negeri Malang \\ Malang, East Java, Indonesia
}

\begin{abstract}
This literary study aims to explain the prophetical dimension in Khotbah di Atas Bukit novel by Kuntowijoyo. The results of the study revealed some dimensions of humanization in the Khotbah di Atas Bukit novel, which include the strengthening of the assertiveness, a sense of social solidarity, and personality. The dimensions of the liberation include the activity of freeing oneself from worldliness and liberation from social inequality. In the dimensions of transcendence, the Khotbah di Atas Bukit novel was concerned with aqidah (belief), khauf(fear), tawakal (submission), and raja' (hope). The dimensions of humanization, liberation, and transcendence represent the ethical prophetic component of prophethood underlying the creation of the Khotbah di Atas Bukit novel.
\end{abstract}

Keywords: prophetic dimension, novel, Khotbah di Atas Bukit

\section{INTRODUCTION}

Indonesian literature has a fast development under the light of the technology industry era. Each author has an essential role in writing literature, especially ideas used for literature. Authors use language to manifest the emotion. Literary works also serve as a manifestation of the social harmony between the individual and the community (Ratna, 2014:99). Literary works also act as a reflection inside the people in many ways (siswanto, 2013:6). Nowadays, literature has many genres the readers can read, and with today's context, readers not only face the genre itself but also with localism and modernity containing Islamic values.

Literary works are a common source of moral values that make the reader's social awareness and religious value grow. Literature that has Islamic touch shows positive, constructive value for the people. The effect resulting from reading literature has a significant influence on the human soul (koesno et al., 2013:140). According to Mangunwijaya (1988:11), literature cannot be separated from the religious dimension, also according to Faruk (2010:181), particularly in Islamic literature.

Nowadays, during social development and culture development, which put the material aspect first, literature needs to express spiritual value as alternative media to see social and humanity in literature text. People's minds are unable to think about absolute justice, and their feelings will dull if they do not touch the real, empiric, transcendence justice (Adz-Dzakiey,88). A new idea emerged in the world of literature called prophetic. According to the Oxford dictionary (2008:125), dimension interpreted as (1) the width, size of the situation, (2) aspect, and way of perspective. According to the Oxford dictionary, prophets are interpreted as humans sent by God to society to give them guidance, message, and predict the future. Word ' prophetic' means as prophetical. The root of the prophetical word comes from Arabic, which means 'nubuwah.' Also, the prophet Muhammad stated, ' Ulama is the heirs of prophets.' It can be summarized that prophetic have similar aspects as a prophet.

Prophetic literature aims to focus its meaning (form and content) to take the 
substance of Islamic values both from the Quran and Hadith, as well as traditions and knowledge born from the interpretation of them. Other names of prophetic literature are prophetic literature, worship literature, da'wah literature, dzikir literature, kaffah literature, prayer literature, and Quranic literature (Effendi, 2011: 38). According to Roqib (2009: 20), Kuntowijoyo has spread a new hope by offering that the rules possessed by this prophetic literature so that later, Muslims can have their paradigm.

The pillar of prophetic ethics itself is taken from the Qur'an Surat al-Imran (3): 110. "You are the best people who are revealed among men to uphold goodness, prevent evil (crime), and believe in Allah." Kuntowijoyo (2013: 4) asserts that the prophetic dimension that can be taken from the three verses is Amar makruf, nahi mungkar, and tu'minuunabillah. Understanding is paired with humanization, Nahi may be paired with liberation, and tu'minuunabillah is paired with transcendence. The verse concept requires a challenge for Muslims to be more open-minded, compete in kindness, work hard, and fastabiqul khairat.

Prophetic literature expresses spiritual and transcendental teachings, which lead to Ilahiyah love (Saryono, 2006: 142). Besides, the study of prophetic literature can be a source of discovery of human identity to get closer to the Divine (Hadi, 2004: 3). Prophetic literature is the reflection of reality, and reality in literature at its core is a symbolic reality, not actual reality and historical reality. Through this symbol, literature gives direction and criticizes reality (Kuntowijoyo: 2005: 10). The aesthetics of prophetic literature combine dimensions of social and transcendental dimensions in human life (Trianton, 2013: 214).

Prophetic literature has few dimensions of humanization, liberation, and transcendence that contain a moral message to invite to good, to benefit together through its beautiful words (amar makruf). The essence of amar makruf, which is called humanity, is to elevate the human degree compared to other creatures. Human shout is bad as asfala safilin, as bad as a creature. Humanization can be a form of strengthening one's personality and activity to assert feelings correctly and strengthen the sense of solidarity.
Nahi mungkar (liberation) in everyday life is self-liberation from all the entanglements that hold people from the oppressive socioculturalism and enslave it, such as preventing shirk, greed, persecution, jealousy, envy, slander, pride, revenge, and vile. Liberation is necessary to prevent and fight against various forms of oppression, occupation, exploitation (groups) of humans against (other groups) of humans. Liberation also tries to free itself from fetters in the circle of worldly life. It is freeing oneself from the influence that brings harm. Muslim actions should be tested to eradicate evil, evil so as not to bring wrath from Allah SWT. Hadi (2004: 1) emphasizes that the prophetic dimension is an important aspect where the center of meeting social and transcendental aspects in literature. Efendi (2011: 66), prophetic literature can be a reflection of reality in literature, which must be part of collective intelligence in people's lives.

The concept of transcendence is paired with tu'minuunabillah, which means believing in Allah. Transcendental literature is literature that seeks to find the spiritual reality behind a symptom. Many things are unknown to humans, such as supernatural, supernatural, and others that are invisible, unless humans can have abilities such as the sixth sense, the inner eye, and get permission from Allah SWT to be able to see it. Transcendence is the development of literature in the direction of human spiritual enlightenment to draw closer to God and seek His pleasure. In the end, through reading, understanding, and appreciation of prophetic literature, the reader will gain inner enlightenment that will enrich the treasures of his life. Prophetic literature has two dimensions, namely the literary dimension of worship and pure literature. The worship literature carried by Kuntowijoyo is an expression of the appreciation of religious values originating from the Qur'an and hadith (Santosa, 2017: 2)

One of the Literary works that contain social life is a novel. The novel is literature in which story structure is shorter than romance and far longer than short stories. The contents of the novel reveal an exciting and essential event from the life of the characters in the novel briefly (Santosa \& Wahyuningtyas 2010: 46). The choosing for Novel Khotbah di Atas Bukit is considered because there are activities that reflect the prophetic dimension in 
narration (including description), prologue, dialogue, and monologue in this novel. This novel has exposure to stories that contain dimensions of prophethood so that later it can be peeled through a focus on the dimensions of humanization, liberation, and transcendence.

\section{Research Methodology}

This study uses a qualitative approach with a type of literature text study (content analysis). This study uses a scalpel in the form of hermeneutics, which aims to interpret and give meaning to the novel. Hermenutika gives a rule of how vital the role of the reader is in determining the meaning of literature. Damono (2005:6) reveals that this hermeneutic approach prioritizes dialogue between the text and the reader in the process of interpretation. Teeuw (1984: 123) explains that the study of hermeneutics in literary works requires an indepth interpretation. Wachid (2006: 220) states that a reader should know everything related to meaning and ideas in the novel.

The data in this study are narratives, prologues, monologues, and dialogues that reflect the prophetic dimension in the Khotbah di Atas Bukit. The prophetic dimensions of focuses are (1) humanization, (2) liberation, and (3) transcendence. Data were collected from the primary data source, namely the Khotbah di Atas Bukit novel by Kuntowijoyo. The step of this research is to collect data, classify data, analyze data, and then report the results of research.

The technique of collecting data uses a documentation study. The data analysis technique of this study consists of three activities that co-occur, namely (1) data reduction, (2) data presentation, and (3) conclusion drawing. The three layers of activity were adapted from Miles and Huberman's work (1992: 18). The flow of this research analysis uses interpretation and a deep understanding of all research data. Furthermore, the data take the form of words, phrases, sentences, symbols, discourses, and dialogues between figures that contain prophetic dimensions. Finally, the collected data are analyzed descriptively to conclude about the prophetic dimension of the novel.

\section{Result and Discussion}

The result of this study is (1) the dimension of humanization, (2) the dimension of liberation, and (3) the dimensions of Khotbah di Atas Bukit by Kuntowijoyo. Data from the three dimensions will be processed and analyzed into prophetic subdimensions. Khotbah di Atas Bukit.

\section{The dimension of Humanization in Khotbah di Atas Bukit}

There are several sub-dimensions of humanization in the novel that include (1) activities that show personality, (2) activities that show assertiveness, and (3) activities that show social solidarity. This novel also reflects the mistake of humans. As the attitude of the followers of Barman, where they come mostly poor people on the market. They lamented his life and regarded Barman as a "savior" who was able to lift the degree of human life for the better. This event indicates the existence of humanization dimensions related to assertiveness. The activity is marked by words, attitudes, and behavioral expressions that express thoughts and feelings with a firm, frank, open and honest attitude. It can be observed in the quote below.

\footnotetext{
"Kami gelisah, Bapak! Tanpa engkau!" kata seorang di belakang. Beberapa orang bergabung dalam malam itu. Mereka yang menuruni lereng-lereng dengan obor segera mengenal kembali Barman yang duduk di atas kuda. Setiap orang yang muncul dan bergabung selalu berseru, "Bapak, jangan tinggalkan kami!". Orang-orang mencoba memegang kaki Barman, mereka seperti ketakutan.

"Jangan pergi ya Bapak," kata
seorang.
"Itu tak mungkin, nak." Kata Barman.

"Kami cinta padamu, Bapak, kami mengharapkan Bapak."

"Tanpa engkau Bapak, kami sendirian"

"Kami membutuhkanmu."

"Tidak dapat lagi dipisahkan."

Malam itu terdapat kerumunan yang seketika berubah menjadi ratapanratapan.
} 
"Tenanglah, aku tidak akan meninggalkan kalian." (Kuntowijoyo dalam Sitanggang, 2003:121)

The conversation between Barman and Barman's followers shows that activities occur related to the emotional situation at hand. Before ending his life, Barman tried to deliver his sermon (da'wah) to his followers. Da'wah is a human relationship that lives with many thoughts and feelings (Tajiri, 2015: 58). This event is related to the dimension of humanization in the form of activities that show personality.

The message that can be taken from the novel is the obligation of a child to devote to parents. The attitude of this service is shown from the character Bobi to Barman in the form of individual attention. Bobi pays attention to the health of his father, earns a living, and contributes pleasure to Barman's soul. Barman figures live a life of simplicity. The attitude of simplicity is a man's attitude that is modest and not excessive. Barman expressed his attitude in order to show the activity of personality (humanization dimension). Barman experienced a self-reflection, which became a synthesis of the emotional, mental, and behavioral life of Barman himself, as illustrated in the quote below.

"Barman mempelajari kejadian
yang menimpa hidupnya. Ia selalu
ingin menafsirkan hidupnya.
Seandainya saja Humam masih
dapat diajak bicara, laki-laki tua
sebaya itu pasti akan menuturkan
kembali lagi kebijaksanaan
kebijaksanaan. Disanalah ia
berusaha memahami semesta
sendirian. Dan ia sanggup
menerima kesendirian itu.
(Kuntowijoyo, 2003:150).

Humanization (amar makruf) in the prophetic dimension is also implemented in caring for the people of the same nationality, in the sense that they keep reminding each other to goodness. Individuals who live in a community should own empathy. This empathy is an aspect of the activity of strengthening social solidarity. Empathy is an ability to imagine the role or circumstances of others, to create sensitivity that is protection and preventive action for losses suffered by others (Syueb, 2006: 110). Bangunjiwo (2009: 119) states that humans can imitate the principle of dharma marang kulawarga. This principle defines humans to carry out their respective duties according to their abilities in their family environment properly, correctly, and precisely.

As social beings who live within the society, humans should have instilled a kepudulian attitude towards others. This attitude can be demonstrated by social activities, voluntary work, and help. This message is reflected in an incident that happened to Barman on the market when he wanted to notify residents of Human's death. The dimension of humanization in the activity of strengthening social solidarity is reflected in the following quote.

"Tunggu sampai ia siuman, kata
seseorang.
"Kita gotong bung, ayo! Nah,
kakinya. Kepalanya!" beberapa
orang terlihat laki-laki membawa
tubuhnya. centang perenang.
Bagian baju yang tak kuat
jahitanya, sedikit menganga.
Rambutnya yang putih terjatuh
beberapa helai, terpijak-pijak.
Barman dibaringkan di sebuah
warung sayur. (Kuntowijoyo,
2003:122).
Barman menundukkan muka ke
tanah. Tiba-tiba ia tegak,
memandang orang-orang itu.
"Saudara-saudara. Telah pergi
dari bumi seorang manusia
sejati" (Kuntowijoyo, 2003:126).

The quotation above shows the human dimension. This subdimension show solidarity who follow Barman. People want to help each other taking care of barman body.

\section{Liberation Dimension on Novel Khotbah di Atas Bukit}

The quote below includes the dimension of liberation because it shows the aspect of liberation from social inequality, where Popi experiences many life trials that make her suffer. The following quote explains this particular message.

\footnotetext{
"Aku ingin melepaskan diri, Pap.
}

"Apa maksudmu?" 
"Dari (perjalanan) waktu yang

(selama ini) menyiksaku! Dari

(cobaan) hidup! Dari beban

(hidup). Ya, itulah

kepercayaaanku (selama ini),

Pap. Eh, (ajaran) agamaku,

mungkin". (Kuntowijoyo,

2003:50).

Based on the quotation, it is illustrated that Popi wants to escape from the time that she considers full of trials and burdens. Popi explains that a person must still make a difficult decision in life. Popi has a speck of faith in his religious teachings that humans want freedom from the social inequality that afflicts them.

The attitude of life reflected in the character of Barman is inversely proportional to the character Humam. Humam has a tremendous spiritual attitude in living his life, even though Humam lives the rest of his life with concern, the Humam act is capital to prepare for death. The figure of Humam is described as a character with the potential of self-actualization of the Barman. That is, the human figure is a manifestation of Barman if he wants to improve himself in the context of 'resting in the quiet and peaceful mountain.' Barman himself has the desire to change like Humam.

The nature of Humam shows freedom from worldliness (zuhud). Zuhud is a human activity in terms of abandoning worldly matters. Humam does not expect the luxury of the world at all and accepts it as it is. Humam figure wants to position themselves as if very long life is an afterlife. Humam does not care about the hustle and bustle of the world. This part of characterization is implied in the following dialog.

\footnotetext{
"Lupakan semuanya, bahkan dirimu". Yang ada disini adalah pohon-pohon, rumput-rumput. Hidup sekedarnya, bahagia sebesarnya (Kuntowijoyo, 2003:72).
}

Barman's attitude changed completely, especially after Humam died. Barman tried his best to break away from dependence on Popi and, at the same time, avoid free sex, which was prohibited by religion. Barman wanted to teach the things he got from Humam to those around him. However, Barman's attitude was ironic because he had no prior religious knowledge. His behavior was simply based on his desire to emulate the figure of Humam. When many people ask for their fatwa, he does not want to answer. The attitude of Barman shows himself the drought of inner and spiritual knowledge.

"Ini khotbahku," katanya. Puncak
itu hening. Dan kuda putih itu
berdiri tegap, menahan tubuh
Barman. Barman masih sempat
mendengarkan suaranya yang
memantul di pohon-pohon. Ia
meneruskan. "Hidup ini tak
berharga untuk dilanjutkan".

At the end of the story, tragically, the character Popi has intercourse with someone he met on the market. Since the story from the beginning to the end, Popi has not undergone a personality change to get better. She still has an instinct as former prostitutes immediately appeared on the surface when there was an opportunity. She did not think of his actions, which caused sin and calamity. It indicates how difficult it is for humans to live on the path of truth to reach God's blessing. Here is the importance of the liberation dimension in the context of preventing the mischief of adultery. Anwar in Widowati (2017: 8) states that the prevention of mishaps carried out by writers in their work must be carried out based on the rules of law, ethics, prevailing norms, and Islamic teachings.

Kuntowijoyo emphasized many elements of Javanese literature to support his narrative as a message of moral, spiritual, and hermeneutical dimensions. Khotbah di Atas Bukit explores human life to the fullest and meaning also the message of god to improve the way of life. Barman, in his past, is a person who tends to be free to obey his desires with Popi. At the end of his life, he killed himself. Popi regrets his departure to follow her passions back by being a wild woman.

Humam interpreted as a religious figure who has a life that is free from all worldly things. The thoughts and actions of Humam reflect the principle of liberation in prophetic literature. Humam frees all the burdens of the mortal world. The last sermon delivered by Barman is aimed to ask his followers to do goodness, but, at the end of his life, he did it in the wrong way. Barman wants to find ultimate 
happiness before adventuring on the hill, which includes the dimensions of transcendence in the form of tawakal. It would be helpful before knowing God, then recognize the Messenger of Allah as Nabiyullah.

The next one is liberation from the turmoil of life and Humam's life anxiety in the mortal world. This activity includes freeing oneself from worldliness. The aforementioned is deemonstrated in the following dialog.

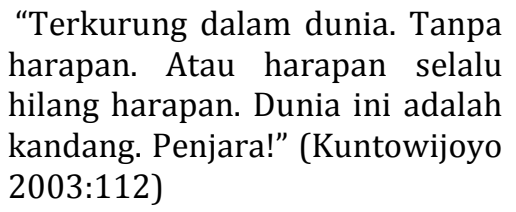

According to Rumi (2017:22), the society that has experienced a multi-dimension crisis needs to back to the spiritual values of religion. Humans quickly struck by nihilism and despair if they stop being a spiritual being.

The novel Khotbah di Atas Bukit illustrates the actualization of prophetic literature as a medium of cultural preaching that has the potential to provide spiritual enlightenment to its readers. In another perspective, Bangunwijaya (2009: 126) says jayeng bhaya as an effort to deal with, overcome threats, challenges, disturbances, and try to avoid any actions that cause harm or evil. It is related to the principle of liberation or injustice.

\section{Transcendence Dimension on Novel Khotbah di Atas Bukit}

Barman interpreted as an old man who does not prepare themselves for essential life in the hereafter (Sitanggang, et al., 2003: 129). He prefers to enjoy his beautiful and sweet life. The quotation below shows that humans naturally should believe at the end of the day. It indicates the aspect of faith in the dimension of transcendence. Barman stated that his conviction on the last day must have arrived, where the final day was the fifth pillar of Islam.

"Dan mati? Ia bertanya. Ialah kalau kita tak lagi punya gerak. Dan engkau tidak takut? Justru yang paling tidak menakutkan". (Kuntowijoyo, 2003:48).
The worst of Barman's actions was suicide, where Allah SWT did not bless this act. This action confirms Barman has lost the grip of life. It includes the dimension of transcendence, which is in the aspect of the trust towards Allah's SWT iradah. Bafadal and Saefullah (2006: 119) state that tawakal is a human attitude that exerts all its ways, all its work to God after trying. Tawakal is accompanied by full-souled action and perfect trust. In this novel, Barman has difficulty finding a way out of his life, so he chooses to resort to suicide. Barman has gone through a long and tortuous process in seeking closeness to God, but he failed and finally put his trust at the end of his sermon. It is reflected in the quote below.

"Bunuhlah dirimu". Tiba-tiba
mereka berhenti. Kabut tersibak
oleh angin. Ada ringkik kuda ang
dahsyat. Kemudian seolah kuda itu
terbang. Suara kemerosak di
bawah. Mereka tercengang.
Menggosok-gosok mata yang
memedas. Penjaga malam itu
berteriak. "O, ke manakah Bapak
(Kuntowijoyo 2003:234).

The experience of mystical events is explained by the presence of a white horse flying shortly before the death of Barman. Although at the beginning of the story Barman was happy when he was with Popi, he still needed to find his identity again, especially after his meeting with Humam. Barman is actively seeking how true happiness, namely life in the hereafter. Barman's fate in this novel is dogged by worry, anxiety, especially when looking for the ultimate purpose of human life. Barman is still skeptical of his own beliefs about life goals in this world. Belief is an element that can change the ordinary vibrations of thought, which comes from the limitations of people's minds into a religious one (Hill, 2009: 47). Humans are created in sibghah-Allah (dyeing, which means faith in God) and thus need to maintain it through physical and inner purity.

Popi is a character who always fought for Barman. However, because of his sin, his efforts always failed. It was shown by Popi when trying to make a quasi-religious congregation. Barman figures who initially wanted to find true happiness but became hopeless or 
pessimistic about the life he lived after meeting with Humam figures whom he believed had a happy life and different from the lives of most people. Barman figures also want to follow in the footsteps of Humam, but misunderstand the teachings that Humam gave him. Finally, Barman's character was desperate and chose to end his life, even though suicide was not worthy of being imitated by his followers.

In the book The Religion of Java, published in 1960, a study of priyayi is a manifestation of religiosity in Javanese society. Priyayi, at that time, became a social class that could be a symbol of organization, culture, religion, power, and even politics in a country (Kuntowijoyo, 2018: 156). The wisdom of Barman's prophetic journey is that Muslims are obliged to believe in Allah to study tauhid. According to Efendi (2011: 182), tauhid is a force that forms the most rooted transcendental structure, which includes the creed, worship, morals, shari'a, and muamalah.

In the dimension of transcendence, it is only natural that human relations as a weak entity before Allah SWT is well spelled in the novel. The closeness of human relations with God will certainly bring feelings of peace and happiness. People who feel close to God will try to do what 'pleases' Allah SWT. The dimensions of humanity and liberation can be categorized as the implementation of hablumminannas, whereas in the transcendence dimension hablumminallah can be implemented. As in the opinion of Husin (2017: 27) on the dimensions of hablumminannas can be described as individual relations, relations with society, and relations with leadership. Including the belief that all humans will die, as well as followers of Barman have buried Barman's body, with deep contemplation. Below are aspects of the dimensions of transcendence in the form of the king's aspect (full of hope).

"Kita sudah menguburkan Bapak kita. Lihatlah, tangantangan kita masih kotor. Tanah ini suci, jangan dicuci tanganmu. Di sini telah dikuburkan sahabat, Bapak dan Juru Selamat kita. Ia telah mengajarkan sesuatu pada kita. "Lihatlah bulan, sekarang Bapak sedang mendaki ke sana. Hidup di sebuah tempat teduh yang abadi!" Yang terkubur disini

Adalah Pemenang!

Menang!”. (Kuntowijoyo,

2003:242).

The quotation above is an aspect of the transcendence dimension that signifies the impression of a Sufistic form, namely, hope (king '). Raja 'is an attitude that shows only a sense of hope in God (Ramadhaniar, 2017: 98). A resident hopes Barman has arrived at a glorious place beside Allah SWT. People who work around the market also feel fear (khauf), because they are worried about the sin they have committed. Khauf is an attitude that shows fear of Allah SWT for the greatness of the essence. They also realized that they had not been able to face the painful reality of Barman's death. Below is explained about Barman's followers' dialogue.

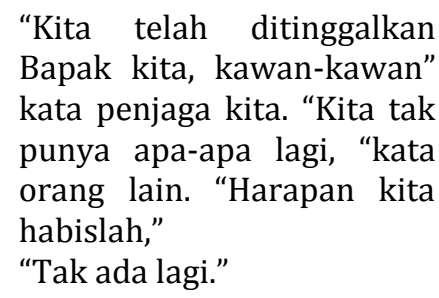

The above quote shows the activity of khauf marked by feeling afraid of being accompanied by worry and anxiety. It is because Barman's followers are afraid of losing the figure who serves as a guide to their lives. Barman's followers here were surprised after Barman committed suicide, and they were not ready to lose Barman.

Humans should only be afraid of God. It is reflected in the Qur'an Ali Imran verse 175, which says that only to Allah is the feeling of fear directed. It is the opposite of what was discussed by Barman's followers, who experienced soul shock over the death of Barman and their friend, Mr. Jaga. It is illustrated in the following statement.

\author{
"Kita tersesat, terasing!" \\ “Tak berarti.” Tak ada gunanya!” \\ "Hidup kita sia-sia. Kosong". \\ Kekosongan yang abadi
}

(Kuntowijoyo, 2003: 236) 
The principle of transcendence or tu'minuunabillah can be linked to one of the contents of the five dharma. It is a teaching to the orientation of human consciousness in determining its vision and mission; Humans can imitate dharma marang hingkang akarya jagad, where humans carry out noble deeds as a manifestation of the obligation of the people to Sang Creator. Usmani (2015: 39) says that humans are expected to emulate the attitude of the Prophet and love Allah as the Creator of the Prophet Muhammad. Hadi (2004: 160) says that humans must be aware that they are servants who serve as well as God's representatives on earth. Humans are created by God to always devote themselves to Him (Bangunjiwa, 2009: 123). According to Kuntowijoyo (2001: 19), when a member of a community shows faith and piety, but the institution is not godly, it can lead to a society full of disbelief. It is the critical role of the combination of faith and piety individually and institutionally. The dimensions of humanization, liberation, and transcendence should go side by side to harmonize social, nation, and state lives.

\section{CONCLUSION}

The results of the data analysis and discussion show that the novel Sermon on the
Mount represents the prophetic dimension. The prophetic dimension in the novel can be used as a contribution to literary learning activities, where students can interpret life inspired by the prophetic dimension itself.

The findings of the data in this study are the prophetic dimensions, which consist of (1) humanization, (2) liberation, and (3) transcendence. The three conclusions are summarized below. First, the humanization dimension is primarily aimed at strengthening the firmness, personality, and social solidarity of each character. It is because the novel is an imaginative work about Barman's life journey to seek his identity in the worldly scope towards the life of the ukhrawi. Second, dimensi liberasi dalam novel Khotbah di Atas Bukit dominated with liberation activity from worldly matter (zuhud). The novel also tells the story of Barman, who has similarities with the character Humam. It is also closely related to the zuhud aspect, where zuhud is an activity that reflects the nature of accepting what he already has. Third, transcendence dimension in novel Khotbah di Atas Bukit more dominated by khauf and raja '. Transcendence in the Sermon on the Sermon on the Mount tends to represent Sufistic activities in the form of khauf and raja'.

\section{REFERENCES}

Adz-Dzakiey. (2005). Prophetic Intelligence: Kecerdasan Kenabian. Yogyakarta: Islamika.

Ahimsa-Putra, H.S. (2016.) Paradigma Profetik Islam. Yogyakarta: UGM Press.

Bangunjiwo, K. J. (2009). Belajar Spiritual bersama "The Thinking General". Yogyakarta: Jogja Bangkit Publisher

Damono, S.D. (2005). Jurnal Ilmu Bahasa dan Sastra, Vol III no. 1 Lingua. Malang: UIN Maliki.

Efendi, A. (2011). Dimensi Profetik dalam Fiksi Kuntowijoyo. Disertasi tidak diterbitkan. Malang: Pascasarjana Universitas Negeri Malang.

Faruk. (1994). Pengantar Sosiologi Sastra. Yogyakarta: Pustaka Pelajar.

Trianton, T. (2013). Dimensi Profetik Ahmad Tohari dalam Khazanah Budaya Cablaka. Jurnal Kebudayaan Islam (Online), 11 (2): 211 (http://www.ejournal.stainpurwokerto.ac.id), diakses 25 Februari 2019. 
Hadi, W.M. (2004). Hermeneutika, Dimensi dan Religiusitas: Esai-Esai Sastra Sufistik dan Seni Rupa. Jakarta: Matahari

Hadi, W.M. (1999). Kembali ke Akar, Kembali ke Sumber: Esai-esai Sastra Profetik dan Sufistik. Jakarta: Pustaka Firdaus.

Hill, N. (2009). Think and Grow Rich. Jakarta: Gramedia Pustaka Utama.

Husin, A. (2017). Dimensi Religiusitas dalam Novel Api Tauhid Karya Habiburrahman El Shirazy. Disertasi tidak diterbitkan. Malang: Pascasarjana. Universitas Negeri Malang.

Kuntowijoyo. (2001). Muslim tanpa Masjid: Esai-esai Agama, Budaya, dan Politik dalam Bingkai Strukturalisme Transendental. Bandung: Mizan.

Kuntowijoyo. (2006). Maklumat Sastra Profetik. Yogyakarta: Grafindo Litera Media.

Kuntowijoyo. (2018). Petani, Priyayi dan Mitos Politik. Yogyakarta: Basabasi.

Kuntowijoyo. (2003). Khotbah di Atas Bukit. Jogjakarta: Bentang Budaya.

Koesnoe, dkk. (2013). Ilmu Hukum Profetik. Yogyakarta: FH UII Press.

Ma'arif, S. (2005). Muslim Tanpa Mitos: Dunia Kuntowijoyo. Yogyakarta: Ekspresi Buku.

Mangunwijaya, YB. (1988). Sastra dan Religiousitas. Yogyakarta: Kanisius.

Maskur. (2012). Ilmu Sosial Profetik Kuntowijoyo (Telaah atas Relasi Humanisasi, Liberasi, dan Transendensi). Tesis tidak diterbitkan. Makassar: Pascasarjana UIN Alauiddin.

Ratna. N.K. (2008). Teori, Metode, dan Teknik Penelitian Sastra: Dari Strukturalisme Hingga Poststrukturalisme Perspektif Wacana Naratif. Yogyakarta: Pustaka Pelajar.

Roqib. (2009). Kontekstualisasi Filsafat Budaya Profetik dalam Pendidikan (Kajian Ahmad Tohari). Disertasi tidak diterbitkan.

Rumi, J. (2017). Masnawi Senandung Cinta Abadi. Terjemahan Abdul Hadi. Yogyakarta: IRCiSoD.

Santosa, W.H., \& Wahyuningtyas, S. (2010). Pengantar Apresiasi Prosa. Surakarta. Yuma Pustaka.

Santosa, P. (2017). Kritik Hermeneutik Sastra Kenabian. Yogyakarta: Elmatera.

Saryono, D. (2007). Mosaik Sastra Indonesia. Malang: Surya Pena Gumilang.

Sitanggang, Sasmito, J.A. Trisna, M. (2003). Religiusitas dalam Tiga Novel Modern: Kemarau, Khotbah di Atas Bukit dan Kubah. Jakarta: Pusat Bahasa Departemen Pendidikan Nasional.

Siswanto, W. (2013). Pengantar Teori Sastra. Malang: Adiya Media Publishing.

Tajiri, H. (2015). Etika dan Estetika Dakwah: Perpspektif Teologis, Filosofis, dan Praktis. Bandung: Remaja Rosdakarya.

Teeuw. A. (1984). Sastra dan Ilmu Sastra: Pengantar Teori Sastra. Jakarta: Dunia Pustaka Jaya.

Thal'at, I. (2018). 55 Nasehat Bagi Wanita sebelum Menikah. Jakarta: Pustaka Azzam. 
Tim Penyusun Kamus. (2008). Oxford Learners Pocket Dictionary. New York: Oxford University Press.

Umar. (2010). Agama Moderat: Menghidupkan Kembali Hakikat Ajaran Islam. Terjemahan Ahmad Dairobi. Jakarta: Nurani Publishing.

Usmani, A.R. (2015). Pesona Akhlak Nabi. Bandung: Mizan Pustaka.

Wachid B.S. Sastra Pencerahan. Yogyakarta: Penerbit Saka.

Waluyo, J. H. 1995. Teori dan Apresiasi Puisi. Jakarta: Erlangga.

Widowati. Materi Nilai Sastra Profetik Kumpulan Cerpen Rusmi Ingin Pulang Karya Ahmad Tohari. Jurnal CARAKA, Volume 4, Nomor 1, Edisi Desember 2017.

Wulananda, R. 2017. Dimensi Profetik Novel Khotbah di Atas Bukitkarya Tasaro G. K. sebagai Sumber Pendidikan Karakter. Tesis tidak diterbitkan. Malang: Pascasarjana Universitas Negeri Malang. 